\title{
Differences wellness among students in guidance and counseling major FKIP UHAMKA Early And Year End Year Class
}

\author{
Fatma Nofriza $^{1 *}$, Dony Darma Sagita ${ }^{1}$ \\ ${ }^{1}$ Universitas Muhammadiyah Prof.Dr.HAMKA, Jakarta, Indonesia \\ *Corresponding author, e-mail: ftm.riza70@gmail.com
}

\begin{abstract}
The background of this research is the emergence of diverse and confusing behavior between students of UHAMKA phenomenon who stay in first and last term on the major counseling. This study aims to describe differences between them in wellness condition. This research was conducted on the students of the Guidance and Counseling majors, Faculty of Teacher and Education Science in the fisrt and last semester. The population of this study supports 147 people in a group and 197 people in B group. The sample was 177 people in a group and 69 people in B group. Sampling technique used is random sampling that. This research uses quantitative methods of comparative approach. The Data in this research is the normal distribution but not homogeneous so that the applied technique of nonparametric analysis of data with the test method of hypothesis U-test (Mann Whitney). Based on the calculation result of the U-test (Mann Whitney) Obtained Z>observed Ztable(22.574>1.96) the which means H0 rejected. The results of this study concluded that there are differences in the level of wellness between a groups of samples, with the wellness of students who stay in last half is much larger than the Guidance Counseling Major student Who stay in the first half.
\end{abstract}

Keywords: Wellness; Last semester; First Semester; Guidance and Counseling major student

How to Cite: Nofriza, F., \& Sagita, D. D. (2018). Differences wellness among students in guidance and counseling major FKIP UHAMKA Early And Year End Year Class. International Journal of Research in Counseling and Education, 2(1), 40-44. https://doi.org/10.24036/0020za0002

\section{Introduction}

Health yourself thoroughly known to the concept of Wellness, is now becoming more popular references in compare mental hygiene in seeing one's mental condition. Wellness a concept that is far more configurable thorough because it can assess the health and welfare aspects of ourselves more broadly that it includes six five main dimensions of the form (1) Spirituality (Spirituality);(2) Direction(self-direction);(3) The work and the use of leisure time(work and leisure);(4) Friendship(friendship);and (5) Love (Love). The fifth aspect is certainly to be important aspects in human beings.

No exception to the students as a group of people who are considered to have a strategic role in social change. In fact, students as a part of society that is expected to continue the great role of community development, in fact too many of them have psychological problems. For example, to meet and work on final project, many students are then justifies any means including plagiarism and academic fraud even more. Those problems also indicate that many students who experience psychological problems. They lost the psychological (Psychological Strengths) and lost the ability to achieve Wellness which in themselves. Wellness lot missing from the students themselves, and they continue to live under excessive pressure (overpressure).

Especially the students of Guidance and Counseling which trains prospective teachers hope to have the fifth dimension Wellness. Is much larger because later in community, graduate from guidance and counseling major will lead to the attainment of happiness, health and well-being of the self. Education and skills training are given for four years studying bachelor in guidance and counseling major in FKIP UHAMKA, is expected to increase Wellness in her that serves students with problems in a more sincere, patient, and capable of being wise. 
At the beginning of the year students appeared assumption that the tasks and the lecture is often seen as a burden rather than a liability. Organizations and other student activities are also regarded as a waste of time, but to hang k regarded as compulsory. As for the final year students who are already close to the limit of active lectures, seen also that the Wellness indicated lower of various factors. For example, with an indication of the low productivity of students in producing scientific papers, such as journals, research, written publications. On this basis also researchers are interested in being able to know the condition of Wellness the environment of the University of Muhammadiyah Prof. Dr. HAMKA (UHAMKA) students, as part of the strategic planning UHAMKA to the main campus

\section{Method}

The type of research that will be used is descriptive comparative research. Yusuf (2005: 82) argues that descriptive research is one kind of research that aims to describe a systematic, factual and accurate information on the facts and the nature of certain populations and tried to describe the phenomenon detailed it is, it means descriptive research is research that describes something that is going on as it is. In this case study will be conducted research that reveal and describe what it is and compare the (comparative) regarding student wellness early years of college with a final year student at BK FKIP UHAMKA Prodi.

\section{Results and Discussion}

In the description of the data will be described associated with Mean, Median, Variance and Standard Deviation of the acquired data. The calculation will be done used IBMSPSS 21. The results obtained as follows.

Table 1. Differences Data Description Wellness

\begin{tabular}{|c|c|c|c|c|}
\hline \multicolumn{5}{|c|}{ Descriptives } \\
\hline \multicolumn{3}{|c|}{ Tahun } & Statistic & Std. Error \\
\hline \multirow[t]{10}{*}{ Total Skor } & \multirow[t]{5}{*}{ Tahun Awal } & Mean & 95.61 & \multirow[t]{5}{*}{.084} \\
\hline & & Median & 95.00 & \\
\hline & & Std. Deviation & 8.577 & \\
\hline & & Minimum & 69 & \\
\hline & & Maximum & 116 & \\
\hline & \multirow[t]{5}{*}{ Tahun Akhir } & Mean & 98.47 & \multirow[t]{5}{*}{.099} \\
\hline & & Median & 98.00 & \\
\hline & & Std. Deviation & 8.058 & \\
\hline & & Minimum & 76 & \\
\hline & & Maximum & 116 & \\
\hline
\end{tabular}

It's known that the Mean score Wellness beginning of the semester of 95.61, with a median of 95.00, the amount of variance equal to 73558 and with a standard deviation of 8577 . The maximum value of 116 and a minimum value obtained at 69 . The mean score Wellness of 98.47 final semester with a median of 98.00 , the amount of variance equal to 64.930 and with a standard deviation of 8058 . The maximum value of 116 and a minimum value obtained at 76 .

When seen from Table 1values obtained mean in Student Semester Two early years as a student at 95.61 and Student Semester final eight years as a student at 98.47. The mean value of the average level of welfare themselves (Wellness) at the beginning of Semester Students at 95.61 and the average level of welfare themselves (Wellness) Student Semester final US \$ 98.47. Thus we can say that the level of self-Welfare (Wellness) student in end year than the beginning years.

Process Testing for normality in this study using the Kolmogorov-Smirnov Test. The testing process is done through the help of software (software) IBM SPSS Satistic21.Based on the calculations in IBM SPSS Statistics 21 , is shown the data normality as follows.

The data in Table 2 show that the test results indicate normality of data distribution is not normal. Because the value Asymp. Sig. (2-tailed) $0.000<\square(0,05)$. Testing process homogeneity in this study using Levene Test. The testing process is done through the help of software (sotfware) IBM SPSS Satistic21.The calculation is based on IBM SPSS Statistics 21, is shown as follows homogeneity of data as follows. 
Table 2. Kolmogorov-Smirnov normality Methods

One-Sample Kolmogorov-Smirnov Test

\begin{tabular}{|c|c|c|}
\hline & & Total Skor \\
\hline N & & 16985 \\
\hline \multirow[t]{2}{*}{ Normal Parameters ${ }^{a, b}$} & Mean & 96.73 \\
\hline & Std. Deviation & 8.492 \\
\hline \multirow[t]{3}{*}{ Most Extreme Differences } & Absolute & .059 \\
\hline & Positive & .059 \\
\hline & Negative & -.059 \\
\hline Kolmogorov-Smirnov Z & & 7.714 \\
\hline Asymp. Sig. (2-tailed) & & .000 \\
\hline
\end{tabular}

a. Test distribution is Normal.

b. Calculated from data.

Table 3. Homogeneity Test Method Levene Test

Test of Homogeneity of Variances

Total Skor

\begin{tabular}{|c|c|c|c|}
\hline $\begin{array}{l}\text { Levene } \\
\text { Statistic }\end{array}$ & df1 & df2 & Sig. \\
\hline 57.662 & 1 & 16983 & .000 \\
\hline
\end{tabular}

Data in Table 3 show that the test results show the cultural homogeneity of the data empathy homogeneity data is not homogeneous. Because the p-valueSig. $0.000<\square(0,05)$. These results reinforce the initial assumption that the data obtained is not homogeneous so that the assumption of testing through statistical methods nonparametric becomes stronger to do.

Hypothesis testing is done by using data analysis Mann Whitney. Hypothesis testing is done after the data analysis requirements are not met. The test results of the data analysis showed that the frequency distribution of the data that we test is not normal and is not homogeneous. The hypothesis put forward in this research that there are differences in the level of welfare of yourself(Wellness)students of BK FKIP UHAMKA year study program start and end years of college. The acquired data was tested using IBM statistical program SPSS (Statistical Product and Service Solution) for Window Release 21:00. Hypothesis testing results are as follows.

Table 4 Differences Welfare Self(Wellness)Students Prodi BK FKIP UHAMKA Early Years and Year End Class

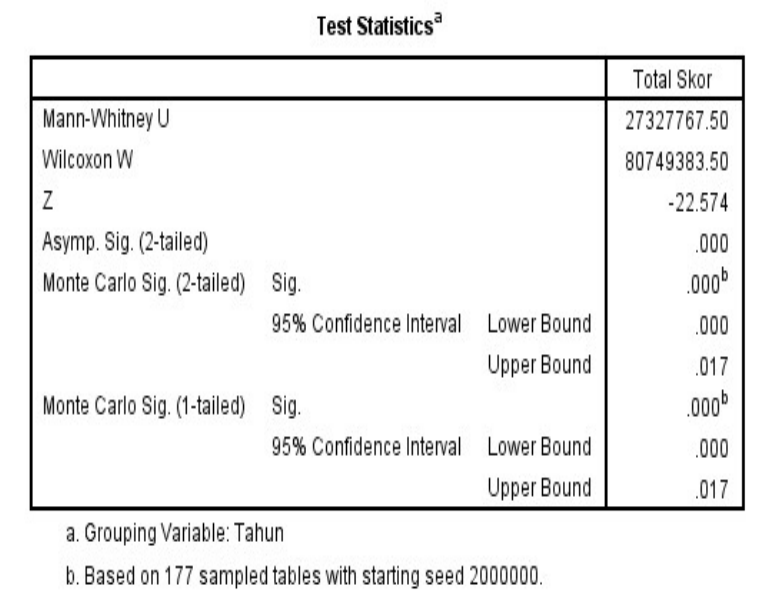


Based on two different test calculations the average data presented in the table above in the column known. Asymp Sig. (2-tailed) have a significance value of $0.000<\square=0.05$. These circumstances mean that there are differences between group A and group B which means that there are differences in the level of welfare of yourself(Wellness)students of BK FKIP UHAMKA year study program start and end years of college. So we concluded that "There are significant differences between the different levels of the Wellness student's guidance and counseling FKIP UHAMKA in early years and the end of the course".

The findings reveal that there are significant differences between the welfare of yourself(Wellness)students of BK FKIP UHAMKA year study program start and end years of college. Then, based on the average level of welfare themselves (Wellness) at the end of the semester students is higher than the average level of welfare themselves (Wellness)Students Semester beginning.

Wellness has become an important topic that focused on the implementation of learning in school. Philosophically, this concept offers a unique approach in educating students to live a healthy lifestyle by means of balancing the tasks of the course so that their quality of life can be healthier. Wellness refers to individual's welfare who have a healthy whole person or multidimensional (health plenary), that the individual in question has a healthy condition in various dimensions of life that includes dimensions: physical, emotional, intellectual, social, spiritual, and vocational. Hawari (2005: 4-5), calling it as a person who has a holistic health. Individuals who have a holistic health that has health four dimensions: physical health, healthy mentally (psychologically), healthy, socially, and healthy spiritually

Based on the research results can seen that emphasize the importance of student have personal healthy (Wellness), the results show student health linked to the development of life skills (personal, social, academic, career and talent development) and student academic achievement. The results seen how the final level students have level Wellness a high compared student early years. Wellness is a form to make students can more positively himself, but looks a lot missing from the students themselves, and they continue to live under excessive pressure (overpressure).

Students in the beginning thought that the duty and the lecture is often regarded as a burden rather than an obligation so that they push themselves to do the work because they orientation is great value. Organizations and other student activities are also regarded as a waste of time, but to hang regarded as compulsory. So they were frightened by the magnitude of the demands that must be fulfilled as a student. Although, for final year students have already approached the limit switches lectures or graduated is also seen that Wellness high caused by various factors. For example, with an indication of the low productivity of students in producing scientific papers, such as journals, research, writing publications and so on.

\section{Conclusion}

Conclusions empathy research on cultural differences between students who live in Rusunawa UHAMKA with BK Prodi students who live at home are the results of this study show the results of the $Z$ value calculated at -22.574 while the value of the $Z$ table on equal significance $\square=5 \%$ (95\% confidence interval) of 1.96. So the value of $Z$ count more $>Z$ tables. As for the value when converted into a value in the table $U$, Asym Sig. (2-tailed) of 0.000 . Value $0,000<\square=0.05$, these conditions mean mensiratkan that there are differences between group A and group B, which means rejecting the null hypothesis (H0) which implies the acceptance of H1. It can also be interpreted with the statement "There are differences in the level of Wellness student's guidance and counseling Major FKIP UHAMKA early years and the end of the course".

Implications of this study show that the assumption has been that consider that the welfare of yourself(Wellness)students Prodi BK at the end of the course students are higher than the beginning of the course, according to the results obtained. Some of the implications of it are presented as follows.

The implications are practical / managerial, shows that the Wellness demand refraction and continuous training on a daily basis. Wellness is not a concept that only requires one is to master the skills of "rote, or reasoning alone" but also should be familiarized in training model. Thus, associated with this method of lectures during the run needs to be strengthened with the assistance efforts and practices as well as the need to be established and structured practice models and strengthening such that between theory and practice, both can thrive hand in hand.

Implications theoretically, encourage the development and strengthening of the understanding of aspects related to Wellness. Development of the theory Wellness is also the future needs to answer the challenges of development throughout life (Life Span Development). Thus the study of empathy in all phases of development, as well as longitudinal studies need to be designed and carried out. 
Implications of the methodology, in this study was associated with excellence and some of the obstacles that passed in the study related to the procedure performed. The advantages associated with the research methodology of research focus on a particular sample. The few things that need to be improved with the methodology is supervision over-variebel uncontrolled variables in the study, so some things can be distracting and lead to the appearance of bias bias is avoided.

Based on the research that has been summarized above as well as related aspects implied praxis, theoretical, and methodological, put forward some suggestions as follows.

Lectures during the time in the neighborhood BK Prodi sought to equip the students' needs in order to establish a student BK reliable and competent in answering the challenges of needs of the times. Especially to the Prodi BK, it is pushing the need for the strengthening and the issuance of a package of measures in the realm of practice in which the achievements of Wellness be integrated with the description of the case (Contextual Learning and Problem Based Learning),the task of observation, and the task of other fields that provide opportunities for students to develop Wellness in life and real social context.

For further research, wellness as the accumulated achievement of personal continue growing throughout life, with the development of a person in a person encourages researchers to dive in and not just in a short time, but in the form of long-term study (Longitudinal Research), this needs to be done in order to collect much more comprehensive data in order to understand the development of the Wellness itself. In addition, researchers also need to expand the range of variables that may affect the development of the Wellness itself. Thus understanding Wellness also be deepened so that we have a complete and comprehensive understanding as the basis for policy decisions in order to develop Wellness among the public at large.

\section{References}

Cambridge. (2009). Cambridge Advanced Learner's Dictionary. Singapore: Cambridge University Press.

Dictionary Development Team Language Center. 2008. Indonesian dictionary. Jakarta: Language Center.

Hidayat, Dede Rahmat and Herdi. (2013). Counseling: Mental Health in Schools. Bandung: Teen Rosda paper

Lubis, Namora Numongga. 2009. Depression: Psychological Review. Jakarta: Kencana.

Meyer's et.al. (2000) The Wheel of Wellness Counseling for Wellness: A holistic treatment models for Planning. Journal of counseling and development Vol. 78 No. 1 Summer 2000

Presentation:"Designingthe road to better health and well-being in Europe" at the 14th European Health Forum Gastrin 7 October 2011, Bad Gastein,Austria.Slide 2.

Riduwan. 2006. Learning EasyResearch.Bandung: PT. Alfabeta.

Sugiyono. (2012). Methods Quantitative, Qualitative, R andD.Jakarta: Alfabeta.

Sukardi. (2003). Educational Research Methodology. Jakarta: Earth Literacy.

Surya Mohamad. (2003). Counseling Psychology. Bandung: Pustaka Bani Quraysh.

Yusuf.AM 2013. Quantitative Research Methods, Qualitative and Research Association. Padang: UNP Press. 